Documento de Trabajo 01/07

\title{
Ownership structure, sharing of control and legal framework. International evidence
}

\author{
Oscar López de Foronda \\ Universidad de Burgos \\ Félix Javier López Iturriaga \\ Universidad de Valladolid \\ Marcos Santamaría Mariscal \\ Universidad de Burgos
}

\begin{abstract}
We analyze the relation between capital structure, ownership structure, and corporate value for a sample of 1,216 firms from 15 European countries. Our results stress two different conflicts of interest and show the differential role played by the mechanisms of corporate control depending on the legal and institutional environment. In common law countries, as a consequence of the relationships between managers and shareholders, capital structure and managerial ownership are the most effective mechanisms of control. In civil law countries, however, as a consequence of the conflicts between majority and minority shareholders, the ownership concentration and the sharing of control within the firm become crucial. In this scenario, the second reference shareholder plays a critical role in contesting the control of the dominant largest shareholder in order to reduce the extraction of private benefits and improve the firm's performance.
\end{abstract}

Key words: Law and finance approach, capital structure, ownership structure, corporate governance.

Dpto. de Economía Financiera y Contabilidad Facultad de CC. Económicas y EE. Avda. Valle del Esgueva 6

47011 Valladolid

Tel. 983423000 (ext. 4395)

Fax 983423299

flopez@eco.uva.es 
DOCUMENTOS DE TRABAJO "NUEVAS TENDENCIAS EN DIRECCIÓN DE EMPRESAS" DT 01/07 http://www3.uva.es/empresa/documentos.php http://ideas.repec.org/s/ntd/wpaper.html 


\section{Introduction}

In recent years, many papers have analyzed the effect on a firm's value of some mechanisms of corporate control (Walsh and Seward, 1990). This literature has often emphasized the specific characteristics of each country and has shown a heterogeneous functioning of control mechanisms depending on the legal and institutional setting.

According to this international approach of corporate governance (Denis and McConnell, 2003; Mintz, 2005), the effectiveness of the mechanisms may be affected by the relationships within the firms and how the rights of stakeholders are protected in each country. While the managers-shareholders relationship is the main source of conflicts in the Anglo-Saxon countries, the ownership concentration originates a new conflict of interest in civil law countries. In these countries, the ownership concentration facilitates the expropriation of wealth from the small shareholders by the largest shareholders. In this case, a second reference shareholder ${ }^{1}$ can contest the control of the main shareholder, reduce the potential for expropriation and impact positively on the firm's value.

Our paper adds to this literature and aims to analyze the differential effect of some mechanisms of corporate control across countries according to the legal characteristics and to the investor protection in each country. To some extent, our paper could contribute to a "contingency theory" of corporate governance, as we show that the functioning of some corporate governance mechanisms is contingent upon the quality and origin of a country's legal institutions. Our findings show that while manager ownership and firm debt are the most effective mechanisms in the AngloSaxon firms, the distribution of ownership and control among shareholders is a crucial mechanism in the Continental European firms.

The role played by a second reference shareholder is the keystone of our paper. Whereas much of the literature has focused on the stake and the identity of the largest shareholder, we still know little about the influence of a second reference shareholder or how they interact with the largest one to improve the performance of the firm. Our results show that both the existence of a second reference shareholder and his stake are significant issues in most Continental European firms. This finding stresses the importance of the coalitions of control among shareholders, and the distribution of power inside the coalitions.

The relevance of our results is twofold. First, for academia and experts in corporate governance, we suggest that the inclusion of the legal and institutional setting could significantly improve the validity of the research. Second, for policymakers, we suggest that reports and codes of good 
governance should explicitly consider the institutional framework of the country, since the mere implementation of good practises from other countries risks being ineffective.

The paper is divided into five sections. Section 2 analyzes previous research into the mechanisms of corporate control and formulates the hypotheses to be tested. Section 3 describes the sample and variables used, and we explain the empirical method. Section 4 shows the empirical results and we assess the degree to which the initial hypotheses are verified. In the final section some conclusions are drawn from the most outstanding results and some directions for future research are suggested.

\section{Institutional framework and corporate governance}

As some authors have suggested, corporate governance aims to solve the core problem of compensation to investors (Shleifer and Vishny, 1997; Denis, 2001). In this scenario, the legal protection of investors becomes a key factor in assessing the influence of the control mechanisms and, consequently, corporate governance interacts with the legal and institutional framework (Mayer, 1998).

There are a number of other institutional factors with a profound impact upon matters of corporate governance. Some studies have analyzed how strong a country's informational regime is, including the leading role of business analysts (Khanna and Palepu, 2004; Dyck and Zingales, 2004), the influence of business schools and management education in enacting agency-like behavior (Ghoshal, 2005), and the political orientation of a country's ruling elite (Roe, 2003). Although we focus on the legal factors of the institutional matrix, there are other institutional factors that could also play a decisive role with respect to the efficacy of corporate governance mechanisms.

The so-called law and finance approach is based on the legal tradition of each country, according to which, countries could be divided into two groups: common law countries and civil law countries. While the law is made by judges in common law countries, legal scholars play a prominent role in civil law countries. Common law countries are basically AngloSaxon nations, whereas civil law countries are from Western Europe. (La Porta et al. 1997, 1998 and 2000; Levine, 1998; Levine et al. 2000; Emmons and Schmid, 2000).

Legal tradition is important due to the different legal protection of investors. Investors' rights are better protected in common law countries. The varying degree of legal protection means ownership structures (La Porta et al., 1999; Himmelberg et al., 2002), corporate finance decisions (La Porta et al., 2000) and development of the banking sector (Levine, 1998) are all different. 
The legal and institutional features are not unrelated to the agency problems within firms. There are two conflicts of interest to which most attention has been paid: the relationship between managers and firm owners and the relation between shareholders and creditors. Nevertheless, in recent years there is more concern with the conflict of interest between large and small minority shareholders. As stated by Becht and Röell (1999) and Bianco and Casavola (1999), in the Anglo-Saxon common law countries, the main agency problem arises from the dispersion of corporate ownership and from a certain lack of shareholder activism. On the contrary, the main problem in civil law countries is the too high concentration of ownership and, consequently, large shareholders may use their voting power to extract private benefits from small shareholders. An alternative view of these agency problems is the existence of a general conflict between managers and all shareholders (more frequent in common law countries) and an agency problem between managers and small shareholders, because managers collude with large blockholders to expropriate minority shareholders (civil law countries).

In turn, the mechanisms of corporate control will play a different role in each institutional and legal environment. Let us review some of the most usual mechanisms and, at the same time, formulate our five hypotheses. The mechanisms we study are basically internal: capital structure and ownership structure, although we consider two different issues in the latter -the influence of ownership concentration and managerial ownership.

\subsection{Capital structure}

Due to the separation between ownership and control, managers' decisions can be driven by perquisites consumption (Jensen, 1986). Relative to equity, debt financing can enhance managerial discipline by reducing the free cash flow and other inefficient managerial actions (Grossman and Hart, 1982; Harris and Raviv, 1991; McConnell and Servaes, 1995).

Therefore, one can expect a positive relation between corporate value -as a consequence of the managers' efficient decisions- and financial leverage. Although debt might also be used to reduce the expropriation of minority shareholders (de la Bruslerie, 2003), capital structure reinforces the control over managers, and therefore a clearer effect of debt could be expected in common law countries, since the problems arising from the managerial relation are most severe in those countries. Consequently, our first hypothesis can be formulated as follows:

Hypothesis 1: A positive relation is expected between corporate debt and the firm's value. This relation will be more important in 
common law countries, where the problem of separating ownership and control is more patent.

\subsection{Managerial ownership}

Previous empirical evidence shows an unequivocal relation between managerial ownership and the firm's value (Morck et al., 1989; Thomsen and Pedersen, 2000). This close link is not a monotonous relationship, since it may combine a convergence effect at lower levels of managerial ownership with an entrenchment effect at higher levels of manager ownership. In coherence with this evidence, our results are therefore expected to show an initially positive effect of managerial ownership. Once a certain level of ownership is reached, this trend switches so that a negative impact of managerial ownership is likely to arise.

Once again, the effect of this mechanism depends on the agency problem it is supposed to solve. For this reason, managerial ownership should play a more important role in common law countries -where the most prominent agency problem is the conflict between external uninformed shareholders and managers- than in civil law countries. Hence, our second hypothesis may be stated as follows:

Hypothesis 2: A firm's value should keep a non-linear relationship with managerial ownership: a positive relation for low levels of ownership and a negative one for high levels of ownership. This relation will be stronger in common law countries.

\subsection{Concentration of ownership}

As a consequence of poor investor protection, corporate ownership concentration is higher in the civil law countries. Then, in firms with quite a concentrated ownership structure, a conflict of interest arises between large and small shareholders (Burkart et al., 1997; La Porta et al., 1999). In contrast, in common law countries, investors' rights are more effectively protected, and ownership is widely held. As a consequence of this structure and the problem of the free-rider ${ }^{2}$, shareholders in these countries have few incentives to monitor managerial actions and delegate in the market for corporate control (Franks and Mayer, 1997). In fact, high ownership concentration has been proved to encourage manager monitoring and to improve firm performance (Demsetz and Lehn, 1985; Bergström and Rydqvist, 1990).

Yet, once again, this relationship must be analyzed in connection with the legal and institutional features. Where investors are best protected against managerial discretional decisions, ownership concentration may not have any significant influence on the firm's value because shareholders do 
not need concentrated ownership structures in order to have their rights protected $^{3}$. The absence of a significant relation for common law countries could even arise as the result of two countervailing effects: a disciplinary role of ownership concentration (in a similar vein as leverage works) which increases firms' performance, and a negative impact due to the problems between large and small shareholders (although less important than in civil law countries).

On the contrary, when the conflict between large and small shareholders is more outstanding, ownership concentration favours a potential risk of expropriation ${ }^{4}$. The wider the decision-making ability of majority shareholders is, the higher the risk of expropriation becomes (Johnson et al., 2000; Gutiérrez and Tribó, 2004). Nonetheless, the possibility of expropriation may present a non-linear effect, since beyond a certain level of ownership, large shareholders bear the costs of their actions to a greater degree and thus the private benefits they may hope to extract will be smaller (Bennedsen and Wolfenzon, 2000; Thomsen and Pedersen, 2001; Claessens et al., 2000). Thus the risk of expropriation is the result of a dual relation between the firm's value and the level of ownership of the controlling shareholders: a decreasing relationship at lower levels of ownership and a positive one for higher levels of the largest shareholder's ownership. All these reasons allow our third hypothesis to be formulated as follows:

Hypothesis 3: The ownership concentration will play a role that depends on the legal and institutional environment. In the civil law countries a non-linear effect might be found, combining a negative relation between ownership concentration and firm value at lower levels of ownership with a positive relation for high enough levels of ownership held by large shareholders. In the common law countries, the chances are that there is no significant relation.

There are also other factors, such as the influence of large shareholders other than the largest one, that may influence the alignment of interests or the expropriation of wealth between shareholders. In firms with multiple blockholders, these large shareholders interact, so that there is no longer a sole shareholder who controls the firm and controlling coalitions must be formed.

The influence of a second reference shareholder is twofold. On the one hand, the second blockholder can form a controlling coalition with the largest shareholder to share diverted profit and, hence, to reduce the performance of the firm. But, on the other hand, the blockholder has incentives to monitor the largest shareholder, reducing profit diversion and improving the value of the firm. The question we should pose concerns the 
conditions under which the diversion of profits can be higher in firms with more than one blockholder than in firms with a single blockholder (Maury and Pajuste, 2005).

Regarding the first effect, the mere existence of a second reference shareholder allows him to collude with the largest shareholder to extract private benefits, as suggested by Bennedsen and Wolfenzon (2000). Furthermore, the bargaining problems between the two largest shareholders may result in a kind of corporate paralysis, reducing the firm's efficiency and hurting the minority shareholders as well.

Bearing in mind that the conflict between large vs. small shareholders is more severe in civil law countries than in common law countries, we formulate our fourth hypothesis as follows:

Hypothesis 4: The presence of a second reference shareholder will negatively affect a firm's value in the civil law countries.

As far as the second effect is concerned, recent research has shown that a firm's value is positively affected by the ability to challenge the largest shareholder (Bloch and Hege, 2001; Gomes and Novaes, 2005; Edwards and Weichenrieder, 2002). The expropriation of minority shareholders is less common in companies where control is most contested and where large shareholders' stakes are not very different, so they have to compete/cooperate for corporate control.

When the main shareholder does not have a dominant position, he needs to form coalitions with other reference shareholders or with a number of minority shareholders. This shared control moderates the discretion of large shareholders and reduces the private benefits they might extract. To some extent, sharing control is a compromise between the excessive monitoring of an outside investor who does not internalize the private benefits, and the excessive discretion of an unchecked controlling shareholder. Likewise, increases in the stake of the second blockholder also increase the expropriating costs that the controlling coalition internalizes. Accordingly, the value of the firm should have a positive relation with the ability of the second reference shareholder to contest the largest shareholder by taking part in the controlling coalition, i.e., with their stake.

In addition, sharing control is likely to protect minority shareholders regardless of a court's ability to detect conflicts of interest in business decisions (Gomes and Novaes, 2005). This means that the effect of sharing control should prevail in countries with the weakest legal protection and law enforceability such as civil law countries. All this leads to our final hypothesis: 
Hypothesis 5: The percentage of ownership owned by the second largest shareholder will positively affect a firm's value in the civil law countries.

\section{Sample and Methodology}

\subsection{Sample and variables}

In order to test our hypotheses, we have combined two databases: financial information and firms' market value have been obtained from Compustat, whereas the information on ownership structure has been drawn from Amadeus ${ }^{5}$. The sample, as detailed in Table 1, includes 1,216 companies from fifteen countries of the European Union between 19972000 , amounting to a total of 3,115 observations.

\section{(Insert Table 1)}

We have defined a number of variables to measure the above mentioned issues. A firm's value has been measured through the firm's market to book value ratio (MB). According to Maury and Pajuste (2005), the firm's market value has been defined as the sum of the market value of equity and the book value of debt. The capital structure has been measured by the debt-to-equity ratio (LEV).

As for ownership structure, three aspects have been defined: managerial ownership, ownership concentration and the features of the second shareholder. Managerial ownership has been proxied by the percentage of shares held by the directors (DIR). Ownership concentration has been measured by the percentage of shares held by the largest shareholder (PROP1). As for the second shareholder, two variables have been defined: a dummy variable (OWNDUM2) and a continuous variable (PROP2), aimed at introducing, respectively, the existence of a second reference shareholder and the proportion of ownership in the hands of this second largest shareholder.

We have also introduced some control variables which, although they are not strict mechanisms of corporate governance, their omission could bias the results. Firstly, dividend policy (DIV) defined as the dividend payout ratio. Secondly, the size of the firm through the log of total assets (LOGAST). The sample can be divided into two groups according to the legal tradition (Table 1).

\subsection{Methodology}

The empirical analysis can be divided into two steps. The first stage is a descriptive analysis aimed at exploring differences in governance structures and their impact on market value in each institutional framework. In the second stage we test the five hypotheses with an explanatory analysis to assess to what extent the control mechanisms help to solve the agency 
problems and thus affect the firm's value. We end this explanatory analysis with some robustness checks of our results to alternative specifications of the model.

Our database combines time series with cross-sectional data allowing the formation of panel data. Our estimations are conducted through the Generalized Method of Moments (GMM), a specific panel data procedure (Arellano and Bond, 1991). GMM has two advantages. First, it controls for the so-called unobservable constant heterogeneity, as represented by the fixed-effects term $\eta_{\mathrm{i}}$, which refers to the specific characteristics of each firm that remain constant over time. Second, it allows the possible problems of endogeneity ${ }^{6}$ to be dealt with. The consistency of GMM estimates depends critically on the absence of second-order serial autocorrelation in the residuals and on the validity of the instruments. For this reason, Tables 5-7 report the Hansen test for over-identifying restrictions that checks the validity of the selected instruments, and auto(2), a second-order serial correlation test.

Our model can be expressed as follows where $i$ equals each individual and $t$ equals time; $\eta_{\mathrm{i}}$ is the fixed-effects term for each individual and $\varepsilon_{\mathrm{it}}$ is the random error for each observation.

$$
\begin{aligned}
& \mathrm{MB}_{\mathrm{it}}=\beta_{0}+\beta_{1} \mathrm{LEV}_{\mathrm{it}}+\beta_{2} \mathrm{DIR}_{\mathrm{it}}+\beta_{3} \mathrm{DIR}_{\mathrm{it}}^{2}+\beta_{4} \mathrm{PROP}_{\mathrm{it}} \\
& +\beta_{5} \text { PROP }_{i t}{ }^{2}+\beta_{6} \text { OWNDUM } 2+\beta_{7} \text { PROP } 2+\beta_{8} \text { DIV }_{\text {it }}+ \\
& \beta_{9} \text { LOGAST }_{\text {it }}+\eta_{\mathrm{i}}+\text { it }
\end{aligned}
$$

\section{Results}

\subsection{Descriptive analysis}

Table 2 displays the mean, median, standard deviation, maximum and minimum value of the most characteristic variables. To explore whether firms in common law countries show differences from those in civil law countries, the mean values are split into two groups according to LAW. Table 2 also shows the $p$-value or maximum level of significance to reject the null hypothesis of equality of means. The $p$-value clearly shows very significant differences between both legal traditions.

\section{(Insert Table 2)}

As regards the valuation of companies, MB shows a significantly higher value in common law countries, consistent with La Porta et al. (1997 and 2002). This underlines the importance of investor protection in the functioning of capital markets.

Concerning the ownership structure, civil law firms exhibit higher ownership concentration (PROP1 and PROP2), consistent with Franks and 
Mayer (1997) ${ }^{7}$. Regarding financial decisions, civil law firms are significantly more financially leveraged and pay out less dividends than common law firms, which agrees with La Porta et al. (2000) and Giannetti (2003). Therefore, as a very preliminary intuition, our data reinforces the idea of two different capital and ownership structures conditional upon the legal and institutional environment.

One concern about our model, as it stands in equation (1), is the possible multicollinearity problem. Accordingly, the variance inflation factor (VIF) is performed, a multicollinearity test, whose results are reported in Table 3, along with the coefficients of correlation between variables $^{8}$. The closer the VIF is to one, the lower the degree of multicollinearity is. As can be seen, VIF is so close to one in all the cases that the absence of multicollinearity can be accepted.

\section{(Insert Table 3)}

In Table 4 the sample is split on the basis of the ownership held by the two largest reference shareholders. Our purpose is to test whether the firm's value can be affected by the presence of a second largest shareholder. The theoretical underlying reason is that the cooperation of this second reference shareholder is outstanding when the main shareholder owns less than $50 \%$ of the voting rights but, at the same time, the combination of the stakes of the first and second reference shareholders exceeds $50 \%$ of the ownership. In Table 4 , we provide the average MB value when PROP1 is under $50 \%$ and we decompose the value depending on whether PROP1 plus PROP2 is under or over $50 \%$. As can be seen, in both legal settings the average value of the firms in which the two largest shareholders own more than $50 \%$ is higher than the value of the firms in which the two largest shareholders do not achieve $50 \%$ of the ownership rights (3.03 against 2.68 and 3.48 against 3.12 ). This suggests that the second shareholder plays a counterbalancing role against the power of the largest shareholder, reduces his private benefits and improves the firm's value when the first shareholder needs the second one to achieve the controlling majority. Furthermore, capital markets react positively to the idea of majority control when such control involves the cooperation of two large shareholders, relying on the moderating role of a second reference shareholder.

\section{(Insert Table 4)}

Therefore, although the results obtained so far are not conclusive, the descriptive analysis corroborates significant differences in terms of ownership structure between the countries from different legal origins. In addition, there seems to be a positive effect of a second reference 
shareholder on the firm's value since he may reduce the problems of majority control by a single dominant owner.

\subsection{Explanatory analysis}

The results of our first estimation are reported in Table 5. These results highlight the unequal relation between debt and the firm's value: while it is significant and positive for common law firms, it is not significant for the civil law ones. This confirms hypothesis 1 , according to which financial leverage has a positive influence on the firm's value by acting as a disciplinary mechanism upon management and favouring the alignment of interests in the common law setting. By contrast, there is no significant relationship between corporate debt and the firm's market value in civil law countries. These results could be explained on the basis of the different agency problems in each environment: corporate debt plays a more important role in the Anglo-Saxon countries due to its disciplining effect upon managers.

\section{(Insert Table 5)}

The results shown in Table 5 also support hypothesis 2. Managerial ownership (DIR) has a positive and significant effect on common law countries. This corroborates the idea that managerial ownership allows the alignment of interests in the countries where the most prominent conflict arises between directors and the owners of the firm. Likewise, the negative and significant coefficient for $\mathrm{DIR}^{2}$ points at a non-linear relationship, so that an entrenchment effect arises for high levels of managerial ownership, and this leads to a lower value of the firm. ${ }^{9}$ On the contrary, we do not find any significant effect for civil law firms. Although this last result deviates from previous research (de Miguel et al., 2004), once again, it can be explained on the basis of the different agency problems in each legal system: in civil law countries there is less separation between ownership and control, and therefore, the managerial ownership is not such a necessary control mechanism.

As regards hypothesis 3, the insignificant coefficients of PROP1 and PROP $^{2}$ do not lend support to ownership concentration as a mechanism of control in either of the two corporate systems. This seemingly conflicting result requires more detailed discussion and additional results that will be introduced below.

As far as the impact of the second shareholder is concerned (OWNDUM2 and PROP2), the results show an asymmetric effect as predicted in hypothesis 4: whereas, in civil law countries, the mere existence of a second reference shareholder has a negative influence, in common law countries, the second shareholder has no impact. This negative impact of a second reference shareholder is consistent with the 
result for PROP2. Coherently with hypothesis 5 , the proportion of equity owned by the second shareholder (PROP2) is positively related to the firm's performance in the civil law countries and has no significant effect in the common law environment.

The joint analysis of OWNDUM2 and PROP2 emphasizes the importance of the second shareholder and his dual role in the control of the firm: the existence of a second shareholder (as introduced by OWNDUM2) originates a conflicting relationship between the two largest shareholders. Yet, simultaneously, the stake of the second reference shareholder (PROP2) is an incentive to deter the extraction of private benefits by the largest shareholder.

This asymmetric behaviour of the second shareholder has much to do with the prevalent conflict of interests in the civil law firms, that is, the relation between large and small shareholders. This conflict has two implications. On the one hand, ownership structures with several shareholders could be detrimental for the firm's performance. In a firm with a sole owner, he bears all the costs of extracting private benefits and hence has incentives to improve the firm's performance. If there was a second significant shareholder (OWNDUM2), whatever their percentage of ownership, a conflict would arise between shareholders and hence the possibility of opportunistic behaviour and the free-rider actions. Consequently, the existence of more than one shareholder has a negative influence on corporate performance because conflicts between the controlling owners of the firm will inevitably arise. In the same vein, the presence of a second blockholder allows controlling coalitions with lower stakes to be formed. This could stimulate blockhoders' expropriating actions as the controlling coalition internalizes a lower proportion of the expropriating costs and thus, could negatively impact on the firm's performance.

Now, once the divergence of interests between shareholders is taken for granted, as a second implication, balanced ownership structures become a way to minimize such costs and the largest shareholder faces more internal contestation. This largest shareholder needs the consent of the second shareholder to pursue his own interests in detriment of small shareholders. In this case, the higher the ownership of the second shareholder, the more difficult will it be for the main participant to expropriate from the other small shareholders. Therefore, the role of the second shareholder is twofold: the fact that equity is not totally owned by a sole shareholder has a negative influence on the value of the firm; but once this issue is accepted, the control of the main shareholder turns out to be easier as long as the second shareholder holds a higher stake on corporate ownership. 
As provisional inferences, our results confirm four out of the five hypotheses and stress the different conflicts of interest within firms in different legal and institutional settings. In the common law system, the most prominent conflict involves managers and shareholders and both managerial ownership and capital structure work as mechanisms to control managerial discretional decisions. On the contrary, in civil law countries, the main agency problem arises between dominant and minority shareholders and, therefore, the ownership structure and the role played by a possible second reference shareholder become vital to improving the firm's performance. Given the critical importance of ownership structure and the lack of empirical support to hypothesis 3 (the effect of ownership concentration), we shall perform an additional analysis whose results are reported in Table 6.

\section{(Insert Table 6)}

Table 6 displays the results of dividing the sample according to the existence of a second significant shareholder ${ }^{10}$. These results can alleviate the above conflicting empirical evidence. In civil law countries, ownership concentration has an outstanding and twofold effect. When there is no second shareholder, ownership concentration combines a negative influence on corporate value (PROP1) with a positive effect (PROP1 ${ }^{2}$ ). In other words, lower levels of ownership concentration facilitate the expropriation of small shareholders by the largest shareholder. However, for high enough levels of ownership concentration, the largest shareholder bears most of the costs and, therefore, the cost of expropriation overcomes private benefits and reduces managerial incentives to expropriate. ${ }^{11}$ In addition, when there is a second reference shareholder, his ability to control the main shareholder becomes quite influential and, consequently, rather than PROP1, the most significant variable is PROP2, an indicator of the internal contestability to the largest shareholder.

However, the possible expropriation of small shareholders by the largest shareholders is not such a relevant problem in the Anglo-Saxon context. In fact, as hypothesized, the proportion of shares owned by the largest shareholder is not significant. In those countries, the most effective mechanisms are corporate debt and managerial ownership -those most closely related to managerial discretion. These results corroborate the different implications of the legal origin of each country for corporate governance and underline the internal contestability as an outstanding issue in civil law firms.

We perform some tests of robustness for our results. First, we have run new estimations with another dependent variable. Instead of MB, we have defined EMB as the equity market-to-book ratio. This variable has been used in the literature to test the impact of financial decisions on a firm's 
value (McConnell and Servaes, 1995). Results are reported in column (1) in Table 7 and, broadly speaking, are consistent with previous ones. The most outstanding results are the dual role of managerial ownership and of the second shareholder in each institutional setting. Managers' stake shows a non-linear relation with the value of the firm (combining the alignment and the entrenchment effect) in the common law countries. In the civil law firms, the presence of a second reference shareholder has a negative impact on firms' performance but, simultaneously, the stake owned by the second shareholder improves the performance of the firm.

\section{(Insert Table 7)}

Another test of robustness focuses on the stake of the possible controlling coalition. We define a possible controlling coalition as the sum of the two largest shareholders. The underlying intuition is that, the higher the stake of the controlling coalition, the larger the proportion of the expropriating costs that the coalition internalizes. Therefore, we have defined PROP1\&2 as the sum of the ownership held by the two largest shareholders. The results of the new estimation are reported in column (2) in Table 7 and provide interesting insights.

As expected, corporate debt and managerial ownership are the most effective mechanisms of control in the common law firms. On the contrary, in civil law firms we should emphasize the influence of the second shareholder and that of the controlling coalition. PROP1\&2 shows a nonlinear relation with the firm's performance: positive for low levels and negative for the highest levels of ownership. This result corroborates the Ushaped influence of ownership concentration and the vital role of the costs of expropriation. When the controlling coalition has a lower stake, both large shareholders can extract private benefits without bearing most of the costs. After a certain threshold of ownership, the internalized costs of expropriation increases so much that they deter the expropriating behaviour of the shareholders that form the controlling coalition and, thus, the firm's performance increases.

Some additional models have been run whose results are not reported for brevity but which are fully consistent with previous ones ${ }^{12}$. We have interacted financial leverage and ownership concentration with the legal and institutional framework as a way to check to what extent the capital structure and the ownership structure are substitutes contingent on the type of country. The results show that financial leverage is complementary to managerial ownership for common law countries while the monitoring of the second shareholder is a substitute for other mechanisms in civil law countries. We have also introduced a non-linear specification for leverage. Its aim is to control for a possible trade-off in civil law firms between the disciplinary role and the bankruptcy costs of debt. The estimated 
coefficients are not significant and, therefore, do not support this intuition. The results confirm the asymmetric role of the control mechanisms and the outstanding importance of the second reference shareholder.

\section{Concluding remarks}

As the law and finance approach has pointed out in the international corporate governance arena, the agency problems are shaped by investors' legal protection. Thus, while in common law countries the main corporate conflict arises between firm owners and the managers who are supposed to run the firm in shareholders' benefit; in civil law countries, the most prominent conflict appears between majority dominant and minority shareholders. In this dual framework, we study the functioning of the mechanisms of corporate governance -more specifically, capital structure and ownership structure- conditional on the legal tradition of the country.

Our results highlight the differential role played by the control mechanisms depending on the legal and institutional setting. The greater separation of ownership and control in common law countries implies that corporate debt can act as an instrument for managers' discipline and has a positive impact on the firm's value. Likewise, in these firms managerial ownership is an effective control mechanism with two different effects: an alignment effect for low levels of managerial ownership and an entrenchment effect for high enough managerial ownership.

In contrast, in civil law firms, capital structure and managerial ownership have no significant influence on the firm's value. In these countries, higher ownership concentration facilitates the expropriation of wealth from small shareholders by the large dominant shareholders. Our results lend support to a non-linear relationship between ownership concentration and firm performance, so that the largest shareholders extract private benefits for low levels of ownership up to a point where the costs of expropriation exceed the private benefits.

Nevertheless, the key aspect of our paper is the power sharing inside the firm and the contestability of the largest shareholder. Unlike the lack of incentives to monitor from a too diluted ownership structure, and the excessive discretion of a dominant unchecked controlling shareholder, our results stress the outstanding role played by the controlling coalition. Consistent with previous research, we find that the existence of a second significant shareholder and his ownership can act as effective counterbalancing factors to monitor the leading shareholder. On the one hand, the existence of a second reference shareholder may trigger a conflict among the significant shareholders and, consequently, reduce firm performance. On the other hand, by owning a higher stake this second shareholder may control the extraction of private benefits by the largest 
shareholder, so the ownership of the second shareholder becomes positively related to the firm's value.

There are several implications from our research, but the sharing of control in firms arises as the most outstanding ${ }^{13}$. Given the growing importance of the conflict of interests between majority dominant shareholders and minority shareholders in most Continental European countries, policy makers should foster stable ownership structures with multiple large shareholders. Since each of these shareholders holds fewer shares than those necessary for control, they need to interact and to share power among themselves by forming controlling coalitions. This shared control protects minority shareholders while preserving valuable private benefits of control. Consequently, the ability of large shareholders to contest the largest shareholder should be encouraged. This suggests a kind of trade-off between preventing the controlling shareholders from harming minority shareholders and allowing them to block inefficient investment decisions.

\section{References}

Arellano, M. and Bond, S. (1991): "Some tests of specification for panel data, Monte Carlo evidence and an application to employment equation”. Review of Economic Studies. 58, pp. 277-297.

Becht, M., and Röell, A. (1999): "Blockholdings in Europe: An international comparison". European Economic Review. 43, pp. 10491056.

Bennedsen, M., and Wolfenzon, D., (2000), "The balance of power in closely held corporations", Journal of Financial Economics. 58, pp. 113-139.

Bergström, C., and Rydqvist, K. (1990): "The determinants of corporate ownership". Journal of Banking and Finance. 14, pp. 237-262.

Bianco, M. and Casavola, P. (1999): "Italian corporate governance: Effects on financial structure and firm performance". European Economic Review. 43, pp. 1057-1069.

Bloch, F., and Hege, U. (2001): "Multiple Shareholders and Control Contest". Groupement de Recherche en Economie Quantitative d'AixMarseille, Document de Travail no. 01A16.

de la Bruslerie, H. (2003), "Controlling Shareholders, Private Benefits and Debt". Available at SSRN: http://ssrn.com/abstract=497305 
Burkart, M., Gromb, D., and Panunzi, F. (1997), "Large shareholders, monitoring, and financial duty", Quarterly Journal of Economics. 112, pp. 693-728.

Claessens, S., Djankov, S., Fan, J.P.H. and Lang, L.H.P. (2000): "Disentangling the incentive and entrenchment effects of large shareholdings". Journal of Finance. 57(6), pp. 2741-2771

Demsetz, H., and Lehn, K. (1985): "The structure of corporate ownership: Causes and consequences". Journal of Political Economy. 93, pp. 1155-1177.

Demsetz, H. and Villalonga, B. (2001): "Ownership structure and corporate performance" Journal of Corporate Finance. 7(3), pp. 209-33.

Denis, D.K. (2001): "Twenty-five years of corporate governance research ... and counting". Review of Financial Economics. 10, pp. 191-212

Denis, D.K., and McConnell, J.J. (2003): "International corporate governance". Journal of Financial and Quantitative Analysis. 38(1), pp. 1-36

Dyck, A. and Zingales, L. (2004): "Private Benefits of Control: An International Comparison". Journal of Finance, 59(2), pp. 537-600,

Edwards, J., and Weichenrieder, A., (2004): "Ownership concentration and share valuation: evidence from Germany". German Economic Review. 5, pp. 143-171.

Emmons, W.R., and Schmid, F.A. (2000): "Corporate governance and corporate performance". Boyd, G., and Cohen, S. (Ed.). Corporate governance and globalization. Edward Elgar. Northampton

Franks, J., and Mayer, C. (1997): "Corporate ownership and control in the U.K., Germany, and France". Journal of Applied Corporate Finance. 9(4). pp. 30-45.

Giannetti, M. (2003): "Do better institutions mitigate agency problems? Evidence from corporate finance choices". Journal of Financial and Quantitative Analysis. 38(1), pp. 185-212

Ghoshal, S. (2005): "Bad Management Theories are Destroying Good Management Practices". Academy of Management Learning and Education. 4(1), pp.75-91.

Gomes, A., and Novaes, W. (2005): "Sharing of control as a corporate governance mechanism". PIER working paper. 01-12.

Grossman, S. J., and Hart, O. D. (1982): "Corporate financial structure and managerial incentives". J. McCall (Ed.): Financial markets and 
financial crises. The University of Chicago Press. Chicago. pp. 107140 .

Gutiérrez, M., and Tribó, J.A. (2004): "Private benefits extraction in closely-held corporations: The case for multiple large shareholders". European Corporate Governance Institute Finance Working Paper $53 / 2004$

Harris, M., and Raviv, A. (1991): "The theory of capital structure". Journal of Finance. 46(1), pp. 297-355.

Himmelberg, C.P., Hubbard, R.G., and Love, I. (2002): "Investor protection, ownership, and the cost of capital". Policy Research Working Paper Series no. 2834

Himmelberg, C. P., Hubbard, R. G. and Palia, D. (1999): "Understanding the determinants of managerial ownership and the link between ownership and performance". Journal of Financial Economics. 53 (3), pp. 353-84.

Jensen, M. C. (1986): "Agency costs of free cash flow, corporate finance and takeovers". American Economic Review. 76(2), pp. 323-329.

Johnson, S., La Porta, R., Lopez de Silanes, F., and Shleifer, A., (2000): "Tunneling", NBER Working Paper Series no. 7523.

Khanna, T. and Palepu, K. (2004): "Globalization and Convergence in Corporate Governance: Evidence from Infosys and the Indian Software Industry." Journal of International Business Studies. 35(6), pp. 484-507.

La Porta, R., Lopez de Silanes, F., Shleifer, A., and Vishny, R.W., (1997), "Legal Determinants of External Finance", Journal of Finance. 52, pp. 1131-1150.

La Porta, R., Lopez de Silanes, F., Shleifer, A., and Vishny, R.W., (1998), "Law and finance", Journal of Political Economy. 106, pp. 1113-1155.

La Porta, R., López de Silanes, F., and Shleifer, A. (1999): "Corporate ownership around the world”. Journal of Finance. 54(2), pp. 471-517.

La Porta, R., López de Silanes, F., and Shleifer, A. (2000): "Agency problems and dividend policies around the world". Journal of Finance. 55, pp. 1-33.

La Porta, R., López de Silanes, F., Shleifer, A., and Vishny, R. (2002): "Investor protection and corporate valuation". Journal of Finance. 52(3) pp. 1147-1170

Levine, R. (1998): "The legal environment, banks, and long-run economic growth". Journal of Money, Credit and Banking. 30(3), pp. 596-620. 
Levine, R.; Loayza, N., and Beck, T. (2000): "Financial intermediation and growth: Causality and causes". Journal of Monetary Economics. 46, pp. 31-77.

Maury, B., and Pajuste, A. (2005): "Multiple large shareholders and firm value". Journal of Banking \& Finance. 29, pp. 1813-1834

Mayer, C. (1998): "Financial systems and corporate governance: A review of the international evidence". Journal of Institutional and Theoretical Economics. 154. pp. 144-165.

McConnell, J. J., and Servaes, H. (1995): "Equity ownership and the two faces of debt". Journal of Financial Economics. 39, pp. 131-157

de Miguel, A., Pindado, J. and de la Torre, C. (2004): "Ownership structure and firm value: new evidence from Spain". Strategic Management Journal. 25 (12), pp. 1199-1207.

Mintz, S. M., (2005): "Corporate Governance in an International Context: legal systems, financing patterns and cultural variables", Corporate Governance: An International Review. 13(5), pp. 582-597.

Morck, R.; Shleifer, A., and Vishny, R.W. (1989): "Management ownership and market valuation. An empirical analysis". Journal of Financial Economics. 20, pp. 293-315.

Roe, M.J. (2003): Political determinants of corporate governance. Oxford University Press. New York.

Shleifer, A., and Vishny, R.W. (1997): "A survey of corporate governance". Journal of Finance. 52(2), pp. 737-782.

Thomsen, S., and Pedersen, T. (2000): "Ownership structure and economic performance in the largest European companies". Strategic Management Journal. 21, pp. 689-705.

Thomsen, S., and Pedersen, T. (2001): "The casual relationship between insider ownership, owner identity and market valuation among the largest European companies", Copenhagen Business School Working Paper no. 15-2001.

Walsh, J.P. and Seward, J.K. (1990): "On the efficiency of internal and external corporate control mechanisms". Academy of Management Review, 15 (3), pp. 421-458.

\footnotetext{
${ }^{1}$ We understand as "second reference shareholder" a blockholder, i.e., a shareholder other than the largest one, who holds at least $5 \%$ of the shares.

${ }^{2}$ This expression refers to the problems of collective action arising when the benefits of one agent's actions are distributed among other agents who neither take part in the action nor share in the costs involved.
} 
3 This assertion could be affected by the ownership structure. For example, banks, that are good at monitoring, diminish the agency problem between managers and shareholders.

${ }^{4}$ Such expropriation could be the transference of assets and profits outside the company in favour of the majority shareholders: sales of assets, contracts in favour of other companies under their control, appropriation of assets in cash, hiring people with family connections, etc.

${ }^{5}$ AMADEUS is a product of Bureau van Dijk Electronic Publishing and provides standardized annual accounts for companies throughout Europe.

${ }^{6}$ Endogeneity might appear when ownership structure, financial leverage or dividends are affected by firms' peformance (Demsetz and Villalonga, 2003; Himmelberg et al., 1999, De Miguel et al., 2004).

${ }^{7}$ Although the results are not presented for brevity, the total proportion of ownership held by the largest, the two, three, four and five largest shareholders is always higher in the civil law countries with a confidence level above $99 \%$.

${ }^{8} \mathrm{VIF}=1 /\left(1-\mathrm{R}_{\mathrm{i}}^{2}\right)$.

${ }^{9}$ According to our data, this critical threshold is situated at a level of around $25 \%$ of director ownership.

${ }^{10}$ This pattern is only followed for civil law firms since, in the common law environment, the ownership dispersion makes the number of firms with a second reference shareholder insignificant.

11 According to our data, this critical threshold is situated at a level of around $80 \%$ of the largest shareholder's ownership.

${ }^{12}$ All of them are available from the authors upon request.

13 Another interesting analysis could be that of multinational firms operating in different legal environments in order to know which kind of agency problems they are affected by the most. 
Table 1: Composition of the sample by countries

\begin{tabular}{|c|c|c|c|c|c|}
\hline \multicolumn{6}{|c|}{ Civil-law origin: 755 firms, 1708 observations } \\
\hline French origin & Companies & Observations & German origin & Companies & Observations \\
\hline France & 270 & 547 & Germany & 146 & 345 \\
\hline Spain & 57 & 141 & Austria & 18 & 42 \\
\hline Holland & 72 & 204 & Total & 164 & 387 \\
\hline Belgium & 36 & 75 & & & \\
\hline Greece & 29 & 62 & Scandinavian origin & & \\
\hline Italy & 2 & 6 & Denmark & 39 & 110 \\
\hline Luxemburg & 1 & 3 & Sweden & 53 & 93 \\
\hline Portugal & 4 & 11 & Finland & 28 & 69 \\
\hline Total & 471 & 1,049 & Total & 120 & 272 \\
\hline \multicolumn{6}{|c|}{ Common-law origin: 461 firms, 1407 observations } \\
\hline Great Britain & 460 & 1,403 & & & \\
\hline Ireland & 1 & 4 & & & \\
\hline Total & 461 & 1,407 & & & \\
\hline
\end{tabular}

Table 2: Descriptive statistics of the main variables

Mean, median, standard deviation, maximum and minimum value of the variables. MB is the market to book ratio of assets; PROP1 and PROP2 the proportion of ownership of the largest and the second largest shareholder; DIR the proportion of managerial ownership; LEV the financial leverage ratio, DIV the dividend payout ratio and LOGAST the log of total assets. The $p$-value is the maximum level of significance to reject the null hypothesis of equality of means between both sub-samples.

\begin{tabular}{|c|c|c|c|c|c|c|c|c|}
\hline \multirow[b]{2}{*}{ Variable } & \multicolumn{3}{|c|}{ Mean } & \multirow[b]{2}{*}{$p$-value } & \multirow[t]{2}{*}{ Median } & \multirow[t]{2}{*}{ Std. dev. } & \multirow[t]{2}{*}{ Max. } & \multirow[t]{2}{*}{ Min. } \\
\hline & Common & Civil & Total & & & & & \\
\hline MB & 3.154 & 2.864 & 2.99 & 0.006 & 1.860 & 3.238 & 21.65 & 0.007 \\
\hline PROP1 & 0.185 & 0.416 & 0.31 & 0.000 & 0.230 & 0.242 & 1.000 & 0.001 \\
\hline PROP2 & 0.088 & 0.127 & 0.11 & 0.000 & 0.086 & 0.094 & 0.500 & 0.000 \\
\hline DIR & 0.079 & 0.105 & 0.09 & 0.000 & 0.000 & 0.192 & 1.000 & 0.000 \\
\hline LEV & 1.486 & 2.287 & 1.92 & 0.000 & 1.395 & 1.851 & 17.97 & 0.000 \\
\hline LOGAST & 2.657 & 2.153 & 2.49 & 0.000 & 2.292 & 0.861 & 5.398 & 0.070 \\
\hline DIV & 0.072 & 0.032 & 0.050 & 0.000 & 0.037 & 0.081 & 1.386 & 0.000 \\
\hline
\end{tabular}




\section{Table 3: Correlation matrix and variance inflation factors}

Pearson's correlations between variables and VIF (variance inflation factor) to test the absence of multicollinearity. The minimum value of VIF is $1 . M B$ is the market to book ratio of assets; PROP1 and PROP2 the proportion of ownership of the largest and the second largest shareholders; DIR the proportion of managerial ownership; LEV the financial leverage ratio, DIV the dividend payout ratio and LOGAST the log of total assets.

\begin{tabular}{lccccccc}
\hline Variables & MB & LEV & PROP1 & DIR & PROP2 & DIV & LOGAST \\
\hline MB & 1.000 & & & & & & \\
LEV & 0.095 & 1.000 & & & & & \\
PROP1 & -0.025 & 0.138 & 1.000 & & & & \\
DIR & 0.031 & -0.034 & 0.235 & 1.000 & & & \\
PROP2 & 0.001 & 0.093 & 0.174 & 0.123 & 1.000 & & \\
DIV & 0.211 & 0.008 & -0.151 & -0.077 & -0.099 & 1.000 & \\
LOGAST & 0.022 & 0.236 & -0.011 & -0.239 & 0.015 & -0.003 & 1.000 \\
\hline VIF & & $\mathbf{1 . 0 9}$ & $\mathbf{1 . 1 2}$ & $\mathbf{1 . 1 4}$ & $\mathbf{1 . 0 5}$ & $\mathbf{1 . 0 3}$ & $\mathbf{1 . 1 2}$ \\
\hline
\end{tabular}

Table 4. Ownership structure and ratio of value

Number of observations according to the ownership held by the two largest shareholders and mean value of $\mathrm{MB}$ in each group. We consider reference shareholders to be those owning at least $5 \%$ of firm's equity. PROP1 measures the proportion of the largest shareholder and PROP2 the proportion owned by the second largest shareholder

\begin{tabular}{ccc}
\hline Panel A: civil-law companies & No. obs & MB \\
\hline Prop1 $\leq 50 \%$ & 961 & 2.79 \\
Prop1+ Prop2 $\leq 50 \%$ & 644 & 2.67 \\
Prop1+ Prop2 > 50\% & 317 & 3.03 \\
\hline Panel B: common-law companies & No. obs & MB \\
\hline Prop1 $\leq 50 \%$ & 1311 & 3.15 \\
Prop1+ Prop2 $\leq 50 \%$ & 1228 & 3.12 \\
Prop1+ Prop2 $>50 \%$ & 83 & 3.48 \\
\hline
\end{tabular}




\section{Table 5: Results of the estimation}

Coefficients and standard errors (in brackets) of the GMM estimation of model [1]. MB is the market to book ratio of assets; PROP1 and PROP2 the proportion of ownership of the largest and the second largest shareholders; DIR the proportion of managerial ownership; LEV the financial leverage ratio, DIV the dividend payout ratio, LOGAST the log of total assets and OWNDUM2 a dummy variable if the company has a reference second shareholder. The Hansen test is informative of the validity of instruments. It follows a $\chi^{2}$ distribution (degrees of freedom in brackets) and auto(2) is a test for the absence of second order serial correlation. ${ }^{* * *}$ for $99 \%$ confidence level, ${ }^{* *}$ for $95 \%$ and ${ }^{*}$ for $90 \%$.

\begin{tabular}{lrc}
\hline Variable & \multicolumn{1}{c}{ Civil } & \multicolumn{1}{c}{ Common } \\
\hline LEV & 0.093 & $1.564^{* *}$ \\
& $(0.255)$ & $(0.779)$ \\
DIR & 10.159 & $17.479{ }^{* *}$ \\
& $(23.447)$ & $(7.786)$ \\
DIR & 25.711 & $-32.4177^{*}$ \\
& $(38.623)$ & $(13.835)$ \\
PROP1 & -15.676 & 6.881 \\
& $(10.905)$ & $(7.705)$ \\
PROP1 & 5.031 & -3.927 \\
& $(11.474)$ & $(8.626)$ \\
OWNDUM2 & $-21.224{ }^{* * *}$ & 0.225 \\
& $(5.980)$ & $(4.000)$ \\
PROP2 & 41.207 & -6.638 \\
& $(13.433)$ & $(5.850)$ \\
LOGAST & $1.666{ }^{* * *}$ & -0.531 \\
& $(0.689)$ & $(0.457)$ \\
DIV & $59.499 * * *$ & 110.23 \\
& $(12.080)$ & $(18.940)$ \\
\hline No. obs. & 1708 & 1407 \\
Hansen test (d.f.) & $40.19(46)$ & $29.87(45)$ \\
Auto(2) & 0.43 & 0.69 \\
\hline
\end{tabular}


Table 6: Results of the estimation

Coefficients and standard errors (in brackets) of the GMM estimation of model [1]. MB is the market to book ratio of assets; PROP1 and PROP2 the proportion of ownership of the largest and the second largest shareholders; DIR the proportion of managerial ownership; LEV the financial leverage ratio, DIV the dividend payout ratio, LOGAST the log of total assets and OWNDUM2 a dummy variable if the company has a reference second shareholder. The Hansen test is informative of the validity of instruments. It follows a $\chi^{2}$ distribution (degrees of freedom in brackets) and auto(2) is a test for the absence of second order serial correlation. ${ }^{* * *}$ for $99 \%$ confidence level, ${ }^{* *}$ for $95 \%$ and ${ }^{*}$ for $90 \%$.

\begin{tabular}{|c|c|c|c|}
\hline & \multicolumn{2}{|c|}{ Civil Law } & \multirow{2}{*}{$\begin{array}{l}\text { Common Law } \\
\text { With } 2^{\text {nd }} S / H\end{array}$} \\
\hline & Without $2^{\text {nd }} S / H$ & With $2^{\text {nd }} S / H$ & \\
\hline LEV & $\begin{array}{r}0.283 \\
(0.268)\end{array}$ & $\begin{array}{r}-0.009 \\
(0.084)\end{array}$ & $\begin{array}{l}1.634 \text { ** } \\
(0.729)\end{array}$ \\
\hline DIR & $\begin{array}{r}1.754 \\
(15.384)\end{array}$ & $\begin{array}{r}-0.019 \\
(3.563)\end{array}$ & $\begin{array}{l}21.988 \\
(7.642)\end{array}$ \\
\hline $\mathrm{DIR}^{2}$ & $\begin{array}{r}16.355 \\
(24.505)\end{array}$ & $\begin{array}{r}1.567 \\
(6.006)\end{array}$ & $\begin{array}{l}-42.4477^{* \star *} \\
(13.782)\end{array}$ \\
\hline PROP1 & $\begin{array}{l}-60.8255^{*} \\
(25.180)\end{array}$ & $\begin{array}{r}-2.518 \\
(2.850)\end{array}$ & $\begin{array}{r}1.451 \\
(7.240)\end{array}$ \\
\hline $\mathrm{PROP}^{2}$ & $\begin{array}{l}36.9888^{* *} \\
(19.046)\end{array}$ & $\begin{array}{r}0.714 \\
(2.990)\end{array}$ & $\begin{array}{r}2.536 \\
(7.192)\end{array}$ \\
\hline PROP2 & & $\begin{array}{r}3.405 \\
(1.920)\end{array}$ & $\begin{array}{r}-7.247 \\
(6.045)\end{array}$ \\
\hline LOGAST & $\begin{array}{r}-1.437 \\
(1.227)\end{array}$ & $\begin{array}{r}0.134 \\
(0.117)\end{array}$ & $\begin{array}{r}-0.619 \\
(0.450)\end{array}$ \\
\hline DIV & $\begin{array}{l}11.3300^{\circ} \\
(6.091)\end{array}$ & $\begin{array}{l}3.590 \\
(0.313)\end{array}$ & $\begin{array}{c}98.558 \\
(16.887)\end{array}$ \\
\hline No. obs. & 306 & 1402 & 1388 \\
\hline Hansen test (d.f.) & $18.89(25)$ & $39.47(36)$ & $29.27(46)$ \\
\hline Auto(2) & -1.39 & -1.23 & 0.49 \\
\hline
\end{tabular}


Table 7: Robustness analysis

Coefficients and standard errors (in brackets) of the GMM estimation of model [1]. The dependent variable is a proxy of Tobin's $q$, the equity market-to-book ratio in column (1) and the market-to-book ratio of assets MB in column (2). PROP1 and PROP2 the proportion of ownership of the largest and the second largest shareholders; DIR the proportion of managerial ownership; LEV the financial leverage ratio, DIV the dividend payout ratio, LOGAST the log of total assets and OWNDUM2 a dummy variable if the company has a reference second shareholder. The Hansen test is informative of the validity of instruments. It follows a $\chi^{2}$ distribution (degrees of freedom in brackets) and auto(2) is a test for the absence of second order serial correlation. ${ }^{\star \star *}$ for $99 \%,{ }^{\star *}$ for $95 \%$ and ${ }^{*}$ for $90 \%$. confidence level

(1)

\begin{tabular}{|c|c|c|c|c|}
\hline Variable & Civil & Common & Civil & Common \\
\hline LEV & $\begin{array}{c}5.5744^{* * *} \\
(1.192)\end{array}$ & $\begin{array}{l}13.9811^{\star \star *} \\
(1.609)\end{array}$ & $\begin{array}{r}-0.195 \\
(0.223)\end{array}$ & $\begin{array}{c}0.910 \text { ** } \\
(0.378)\end{array}$ \\
\hline DIR & $\begin{array}{r}13.432 \\
(46.593)\end{array}$ & $\begin{array}{c}105.34 \\
(50.602)\end{array}$ & $\begin{array}{r}8.829 \\
(8.901)\end{array}$ & $\begin{array}{c}9.205 \text { * } \\
(4.977)\end{array}$ \\
\hline $\mathrm{DIR}^{2}$ & $\begin{array}{r}25.753 \\
(68.941)\end{array}$ & $\begin{array}{l}-179.28 \\
(88.889)\end{array}$ & $\begin{array}{r}9.477 \\
(15.067)\end{array}$ & $\begin{array}{c}-16.010 \text { * } \\
(9.547)\end{array}$ \\
\hline PROP1 & $\begin{array}{r}-83.819 \\
(71.919)\end{array}$ & $\begin{array}{r}-49.534 \\
(61.303)\end{array}$ & & \\
\hline $\mathrm{PROP}^{2}{ }^{2}$ & $\begin{array}{r}62.501 \\
(68.763)\end{array}$ & $\begin{array}{r}85.176 \\
(91.632)\end{array}$ & & \\
\hline OWNDUM2 & $\begin{array}{l}-48.560 \\
(20.809)\end{array}$ & $\begin{array}{l}-232.83 \\
(114.39)\end{array}$ & & \\
\hline PROP2 & $\begin{array}{l}154.71 \\
(65.961)\end{array}$ & $\begin{array}{r}9.295 \\
(9.649)\end{array}$ & & \\
\hline PROP1\&2 & & & $\begin{array}{l}-20.158^{\star * *} \\
(4.970)\end{array}$ & $\begin{array}{r}-0.725 \\
(8.055)\end{array}$ \\
\hline PROP $1 \& 2^{2}$ & & & $\begin{array}{l}20.752 \\
(4.028)\end{array}$ & $\begin{array}{c}-2.724 \\
(9.010)\end{array}$ \\
\hline LOGAST & $\begin{array}{r}4.898 \\
(3.352)\end{array}$ & $\begin{array}{r}-0.530 \\
(1.910)\end{array}$ & $\begin{array}{r}1.028 \\
(0.223)\end{array}$ & $\begin{array}{r}-1.393 \\
(0.933)\end{array}$ \\
\hline DIV & $\begin{array}{r}28.781 \\
(17.919)\end{array}$ & $\begin{array}{c}10.049 \\
(10.718)\end{array}$ & $\begin{array}{l}4.8899^{\text {**t }} \\
(1.337)\end{array}$ & $\begin{array}{r}2.687 \\
(5.241)\end{array}$ \\
\hline No. obs. & 1708 & 1407 & 1708 & 1407 \\
\hline Hansen test (d.f.) & $22.44(26)$ & $32.12(26)$ & $44.91(37)$ & $48.00(46)$ \\
\hline Auto(2) & 0.52 & -1.55 & 0.86 & -0.65 \\
\hline
\end{tabular}

